\title{
Mobile Learning in Malaysian Schools: Opportunities and Challenges of introducing teaching through mobile phones
}

\author{
M. Mohamad ${ }^{1}$, F. Maringe ${ }^{2}$, J. Woollard ${ }^{1}$ \\ University of Southampton, University of the Witwatersrand ${ }^{2}$
}

\begin{abstract}
This study examines the concept of management of change through a consideration of the opportunities and challenges to implement mobile learning via mobile phones in Malaysian schools with data gathered from educational experts in the United Kingdom and Malaysia. The study applies educational research and development (ER\&D) evaluation methodology by Borg and Gall [1] with interview as the research tool. This study contributes towards the body of knowledge of mobile learning in Malaysia where mobile learning is still in its infancy and adds value to enlighten the situation of mobile learning in the country. The research identifies, although Malaysian schools have the potential to implement mobile learning, various challenges need to be addressed to make it a reality.
\end{abstract}

\section{Introduction}

In recent years, there has been an increasing interest in mobile learning using devices varying in size from the large, such as net books, notebooks and laptops to small, like mobile phones and PDAs. Although there are negative perceptions towards the use of mobile phones in mainstream education [2], the potential of mobile phones to support teaching and learning has been discussed frequently in academic literature [3]. Various learning activities conducted with mobile phones have shown positive outcomes [4]. A popular learning application that deploys mobile phones is vocabulary learning [5]. However, the task of implementing mobile learning via mobile phones also has many challenges; some are associated with the negative attitudes and inappropriate uses.

This paper discusses the significance of utilising mobile phones in education and highlights the benefits and convincing reasons of deploying mobile phones in mainstream schooling in Malaysia. The keywords are mobility, bite size lesson, motivation, affordability, personalisation, drill and practice, interactive learning and independent learning. It also discusses the challenges to deploy mobile phones in Malaysian schools through an analysis of management of change. The challenges are grouped around the following key issues: (1) misuse, (2) current educational policy, (3) management and maintenance, (4) stakeholders attitude (5) digital divide and (6) personal space invasion.

\section{Context}

The main motivation behind the deployment of mobile phones in education is mobility. With mobile phones, students can access their lessons almost anywhere and at any time [6] [7]. They are compact and can be transported with ease. They place learning in the hands of the learner. The use of bite size lessons through mobile phones fits in with the students' lifestyle. Bite-size lessons, as defined by [7], are the result of breaking down large and more complex teaching materials into smaller chunks. Mobile phones can support learning by providing learners with bite size lessons that they can learn in shorter periods [8]. Mobile phones also provide an alternative to traditional learning tool such as flash cards. A study by Basoglu and Akdemir [9] established that using vocabulary-learning programs on mobile phones is more effective than using flashcards. Mobile phones offer accessibility and portability that enable students to conduct engaging learning activities anytime and anywhere [7]. Mobile phones also have the potential to be used in promoting digital literacy. As stressed by Hague and Williamson [10] digital literacy is crucial for school children in preparing them to survive in their society. Therefore, school children ought to be familiar with these technologies, for example through the utilisation in educational activities. In Malaysia, students and teachers are expected "to keep abreast" with the latest technology [11]. Mobile phones can also motivate students to learn. Kolb [4] and Saran and Seferoglu [12] showed that mobile phones, which are popular among students is a motivational tool to be used in education.

Williams [13] pointed out that mobile phones are a sensible choice for educational investment. Furthermore, Motlik [14] also stressed that mobile phones are beneficial for both instructors and learners in developing countries, because of its costefficient method. Naismith et al. [15] and Mellow [7] highlighted the affordance of SMS technology that offers push system in the delivery of learning materials. Push system as defined by Naismith et al. [15] and Mellow [7] is where through SMS technology, moderator pushes out mobile lessons to students as reminders to revise. Push systems promote students to have regular study time, especially for students who lack motivation to learn, or who are not organised or who have conflicting pressures. SMS technology is also suitable as a medium for repetition or drill and practice exercises, 
which is particularly beneficial for students in preparing for examinations.

In a report by Shuler [16], it stresses the importance of mobile phones in supporting personalised learning experience. Not all learners are alike; therefore, lessons should be customised according to the students' level of performance, preferred learning styles and preferred ways of working. This is one of the features that mobile phones could support, which Shuler referred as "supporting differentiated, autonomous, and individualised learning through mobile devices" [16]. An associated advantage is that students are able to receive immediate feedback.

Based on the affordances of mobile phones in education, there are a number of trial efforts in deploying mobile phones in mainstream schooling including: Learning2Go based in schools in Wolverhampton, United Kingdom; a trial programme at Cempaka International Ladies' College; Notre Dame High School in Sheffield, United Kingdom; Otumoetai Intermediate School, New Zealand; and Wiregrass Ranch High School in the United States of America [17]. A key to successful introduction of new ideas in education is the concept of change management to which the article now turns.

\section{Management of Change}

Change is difficult to introduce and implement for a wide variety of reasons. These include that it can sometimes be more disempowering than empowering. Causing people to learn new skills requires personal investment of time, effort and sometimes finances; it can be destabilising, moving people away from their comfort zones into new and often more complex ways of working. It is often introduced hurriedly without proper planning and it is often perceived as an intrusion into the working lives of people who see it as unnecessary [18]. Education in particular is a very conservative system that adopts a rather cautious scepticism to new developments [19] yet schools have become more open systems. Teachers and pupils have to work alongside parents, communities, governments, local authorities, businesses, suppliers and service providers involving varying levels and amounts of interaction. Thus, any change that may be introduced tends to have wide ranging impacts on a variety of stakeholders whose interests in the change may be complimentary but frequently could also be contradictory. This makes working with change in schools extremely challenging.

As introducing mobile learning in Malaysian schools is at the heart of this research, it is important to explore briefly the range of theoretical perspectives developed around the need to manage change effectively in educational environments.
Fundamentally, three models of change management have been developed for use in educational environments. These include: the Research Development and Diffusion (RD\&D) model, the Social Interaction (SI) model and the Problem Solving (PS) models.

The Research Development and Diffusion (RD\&D) model is fundamentally based on rationalempirical assumption, which considers people as having a positive inclination towards change that is based on demonstrable scientific evidence. If it can be shown that the envisaged change works and that there is scientific evidence to back it up, then people will adopt the change favourably. In the context of this research, if the scientific evidence of the benefits of mobile learning can be demonstrated clearly to the variety of stakeholders in Malaysian schools, then the chances of successful implementation would be increased. RD\&D models are often criticised for being grounded on a centre-periphery strategy for change management which itself is based on a dynamic of power differentials between the centre and periphery. Because of that, those at the periphery sometimes see the change as an imposition from above.

Social interaction (SI) models on the other hand are not based on the scientific rationality of RD\&D. Rather, they assume that change is supported by people networks working together towards a common purpose [20]. The efficacy of science and rationality are not critically important but what is of significance is to tap into the human network resource that tends to work seamlessly with the innovation providing on-going evidence about the power and utility of the new idea. For example, people who use Facebook and other social networking facilities do so, not because they have been convinced by any scientific evidence that Facebook works, but that their human networks have a common resort to a facility that provides for their needs as a group. The more people join the network, the more it appears that the change is a good idea. SI models are based on an equal sharing of the power dynamic since the interactions are more of a periphery-to-periphery format. The fact that there is no centre in the dynamic could reduce the accountability value of these models of change.

Problem Solving (PS) models are essentially group problem solving models, where people come together using both formal and informal structures to consider ways to enhance the quality of their group or communal lives described in Everett Rogers' Diffusion of Innovators. They have the advantage of being a grassroots based action for change, involving the very people needing the change. The chances of adopting the change are thus quite high given that the change would have been self-determined by the group and the solution would also have been designed by the same group. They have the 
advantage of relevance, but tend to be associated with issues of resource deficiencies and inadequacies. As such, without external help, problem solving tends to rally round the least financially expensive solutions that may not always be the best.

Borg and Gall's [1] Educational Research and Development model was adopted for this study as it combines the advantages of the three models in its eight-step strategy. It utilises empirical rationale, social interaction and group problem solving strategies at various stages through its incorporation of research, net-working interaction in testing out ideas and group synergies in evaluating the power of the mobile technology utilisation as a pedagogical tool in Malaysian schools.

\section{Implementation}

The main objective of the study is to gather opinion from the experts in education regarding the development of the implementation strategy to support mobile phones deployment in Malaysian schools. However, besides the evaluation, respondents' perspectives towards the emerging issues in deploying mobile phones are also explored. The research design is based on the Educational Research and Development (ER\&D) approach by Borg and Gall [1]. The 8 steps applied are research and information gathering, planning, developing the product in preliminary form, preliminary field testing or formative evaluation, main product revision, main field testing or summative evaluation, final product revision as well as dissemination and distribution (See Figure 1).

$$
\begin{aligned}
& \text { Step 1: Gathering information } \\
& \text { Step 2: Product planning } \\
& \text { Step 3: Preliminary development } \\
& \text { Step 4: Preliminary evaluation } \\
& \text { Step 5: Product revision } \\
& \text { Step 6: Field testing } \\
& \text { Step 7: Final production } \\
& \text { Step 8: Dissemination }
\end{aligned}
$$

\section{Figure 1. Steps adopted from ER\&D approach}

This study gathered opinion from the experts in education who were identified through purposeful sampling strategy. The experts in education consulted are English subject leaders, ICT subject leaders, stakeholders from the school management such as head teachers and deputy head teachers from the United Kingdom and Malaysia as well as officers from the Ministry of Education, Malaysia were individually interviewed to capture the respondents' perspective and to obtain additional or better idea towards the development of the implementation strategy. In addition, the interviews also gathered the respondents' perspectives about the emerging issues in implementing mobile learning. The study used HyperTRANSCRIBE, QSR NVivo and Inspiration based on the 3 Cs of analysis: coding to categorising to concepts to identify the themes through text analysis and visualisations of the concepts.

\section{Discussion}

The study established that there are opportunities and challenges to implement mobile learning in Malaysia. The opportunities fields include: English language subject support; proliferation of mobile phones; future teaching and learning tool; other subjects support; affordability; motivational tool and preparing students for the future with digital literacy. Interviews established that the respondents are positive towards the possibility of using mobile phones to support English language subject in Malaysian schools. The pedagogical affordances of mobile phones raised by the respondents include; supplementing English subject outside classroom, supporting interactive learning, supporting drill and practice, supporting systematic learning, raising students' confidence in learning English and encouraging students to become autonomous learner. The proliferation of mobile phones also indicated that mobile phones have the potential to be utilised in mainstream schooling in Malaysia. A respondent stressed that it would be a waste if mobile phones are not considered to be used in education. Another respondent believed that it is inappropriate to discourage students from using mobile phones in learning activities because eventually it will become an ordinary tool for everyone.

The respondents also have a vision that mobile phones could become a teaching and learning tool in the future. They were positive with the possibility of change in education. They believed that there would be changes in the policy at schools that will make it possible to implement mobile learning in Malaysian schools. They predicted that this would happen within five to ten years.

Mobile phones also have the potential to support other subjects and various learning activities. Respondents suggest that mobile phones can be used as an alternative tool to support learning as well as to become a medium of information. The respondents also recognised the affordances of mobile phones to support mobility and interactive learning. Moreover, the mobile phone is also perceived as an affordable tool that should be explored to support teaching and 
learning purpose. Respondents believed that deploying mobile phones would be cost effective compared to desktop computers.

Respondents also highlighted the affordances of mobile phone as an engaging and motivational tool. The respondents were positive that mobile phone would help students to become engaged in their learning activities. They also believed that with the element of fun in using the mobile phones, it would encourage students to be motivated to study. Finally, mobile phones are also perceived as a tool to prepare student with digital literacy. This would help them to survive in the corporate world in the future.

With regard to challenges, the themes arising from the responses are misuse, current policy, management and maintenance, stakeholders, digital divide and personal space invasion. With regard to misuse, respondents believed that misuse is a major challenge that needs to be dealt with to implement mobile learning. The respondents believed that misuse might discourage the government to support the use of mobile phones in education. There are possibility of misuse via MMS and Bluetooth and the issue of cyber bullying was raised. It was suggested that mobile phones that have parental features to control students through limiting the functionality was perhaps necessary.

For the respondents, the current prohibitive policies are a challenge to the implementation of mobile learning. Only with changes in the policy could mobile learning be implemented in Malaysian schools.

Another major is management and maintenance of mobile technologies. Respondents are concerned with the cost in deploying mobile phones for teaching and learning. They also believed that the organisation of mobile learning is time consuming and they consider there to be issues relating to theft, loss and health hazard. Respondents also believed that the stakeholders' attitude might be a challenge to implement mobile learning. The challenges might arise from the students, teachers, parents and the community. Another issue that was raised by the respondents is the issue with digital divide. Although for some respondents the use of mobile phones is cost effective, it might also lead to digital divide as the result of possible cost issue.

The final challenge that was highlighted by the respondents is associated with personal space invasion. For some students, they might be bemused or annoyed with the expectation of using their own mobile phones for educational purposes.

The above challenges illustrate pitfalls of managing change in a top down manner with little or no involvement of various stakeholders including the intended users as an integral part of the change process.

\section{Conclusions}

By considering the words of practising teachers in the UK and Malaysia and consultation with education policy makers in Malaysia, the challenges and affordances of mobile learning through mobile phones have been established. Through considering the models of management of change it is clear that a change such as the introduction of mobile phones into the teaching strategies of schools will benefit from clear central science-base evidential policy supported by case study in the United Kingdom and Malaysia such as: Learning2Go; Cempaka International Ladies'; Notre Dame High School; Otumoetai Intermediate School; and Wiregrass Ranch High School [17]. However, the teachers' responses also indicate that social interaction and grassroots support is a key element of successful implementation of change. The policy should be supportive and sensitive to the range of stakeholders involved. The study has shown that the educational research and development (ER\&D) methodology [1] alongside analysis techniques based on can be successful in identifying the key issues as well as developing a product - a policy statement for the implementation of mobile phones for teaching in Malaysian schools.

\section{References}

[1] Borg, W.R. and M.D. Gall, Educational Research: An Introduction, Longman, New York, 1983.

[2] K. E, Smith, O. Cap, and J. Welsh, "Cheating and Bullying Using Cell Phones and PDAs: The Dark Side of Mobile Technology”, Humanities Conference, Cambridge, United Kingdom, 2-5 August, 2005. Available at: http://ijh.cgpublisher.com/product/pub.26/prod.489 (Accessed: 1 December 2011).

[3] The Horizon Report, “The New Media Consortium”, 2010. Available at: http://www.nmc.org/pdf/2010Horizon-Report.pdf (Accessed: 1 December 2011).

[4] Kolb, L., Toys to Tools. Eugene: International Society for Technology in Education, Washington DC, 2008.

[5] R. Gilgen, "Holding the world in your hand: Creating a mobile language learning environment”, Educause Quarterly Magazine. 28(3), 2005. Available at: http://www.educause.edu/EDUCAUSE+Quarterly/EDUC AUSEQuarterlyMagazineVolum/HoldingtheWorldinYour HandCreat/157359 (Accessed: 1December 2011).

[6] C. Quinn, "mLearning: mobile, wireless, in-yourpocket learning”, LineZine, 2000. Available at: http://ww.linezine.com/2.1/features/cqmmwiyp.htm (Accessed: 1 December 2011).

[7] P. Mellow, "The media generation: Maximise learning by getting mobile”, Ascilite, 2005. Available at: http://www.ascilite.org.au/conferences/brisbane05/blogs/ 
proceedings/53_Mellow.pdf (Accessed: 1 December 2011).

[8] Kenning, M. M., ICT and Language: From Print to the Mobile Phone. Palgrave Macmillan, Victoria, Australia, 2008.

[9] E.B. Basoglu, and O. Akdemir, "A comparison of undergraduate students' English vocabulary learning: using mobile phones and flash cards", The Turkish Online Journal of Educational Technology, 9(3), 2010, pp. 1-7.

[10] C. Hague, and B. Williamson, "Digital literacy across the curriculum”, Futurelab Handbook, Futurelab, Bristol, 2009.

[11] H. Goh, and B. Aris, "Using robotics in education: Lessons learned and learning experiences", 1st International Malaysian Educational Technology Convention, Johor Bahru, Malaysia, 2-5 November, 2007. Available at: http://eprints.utm.my/6015/1/149-henry.pdf (Accessed: 1 December 2011).

[12] M. Saran, and G. Seferoglu, "Supporting foreign language vocabulary learning through multimedia messages via mobile phones", Hacettepe Universitesi Journal of Education, 38, 2010, pp. 252-266.

[13] Williams, B., Handheld Computers and Smartphones in Secondary Schools, International Society for Technology in Education, Eugene, 2006.

[14] S. Motlik, "Mobile Learning in Developing Nations", The International Review of Research in Open and Distance Learning, 9 (2), 2008, pp. 1-7.

[15] K. Naismith, P. Lonsdale, G. Vavoula, and M. Sharples, "Literature Review in Mobile Technologies and Learning”, NESTA Futurelab Series. Report 11, NESTA Futurelab, Bristol, 2004.

[16] C. Shuler, Pockets of Potential: Using Mobile Technologies to Promote Children's Learning, The Joan Ganz Cooney Center at Sesame Workshop, 2009. Available at: http://www.joanganzcooneycenter.org/pdf/ pockets_of_potential.pdf (Accessed: 1 December 2011).

[17] M. Mohamad, and J. Woollard, "m-Learning - an annotated bibliography", University of Southampton, Southampton, United Kingdom, 2011. Available at: http://www.pgce.soton.ac.uk/mLearning (Accessed: 1 December 2011).

[18] Fullan, M., Turnaround leadership, Jossey-Bass, San Francisco, 2006.

[19] Hall, G.E. and S.M. Hord, Change in Schools, facilitating the process, State University of New York University Press, New York, 1987.

[20] Mullins, L.J., Management and organisational behaviour, Prentice Hall, London, 2007. 